\title{
Strategi Pengembangan Bisnis Restoran Makassar Berbahan Baku Hasil Ternak dalam Mendukung Penyediaan Makanan Sehat (Studi Kasus di Restoran Marannu dan Karebosi Kelapa Gading)
}

\author{
Restaurant Business Development Strategy Based on Makassar Raw Results in Supporting \\ The Provision of Animal Health Foods \\ (Case Study of Marannu and Karebosi Restaurants Kelapa Gading)
}

Amrullah $^{1 *}$, Musa Hubeis ${ }^{2}$ dan Nurheni S. Palupi ${ }^{3}$

${ }^{1}$ Universitas Hasanuddin, Makassar

Jl. Perintis Kemerdekaan, Tamalaranrea, Makasar 90245

${ }^{2}$ Departemen Manajemen, Fakultas Ekonomi Manajemen, Institut Pertanian Bogor

${ }^{3}$ Departemen Ilmu dan Teknologi Pangan, Fakultas Teknologi Pertanian, Institut Pertanian Bogor

Jl. Kamper, Kampus IPB Darmaga Bogor 16680

\begin{abstract}
ABSTRAK
Bisnis restoran adalah usaha komersial yang harus dilandasi rasa keinginan mendapatkan keuntungan tertentu, sehingga dalam pelaksanaannya selalu menghitung untung-ruginya dan pada akhirnya mengharapkan keuntungan. Tujuan penelitian: (1) mengidentifikasi faktor internal dan eksternal restoran menu makanan khas makassar, yang dapat memengaruhi perkembangan bisnis restoran; (2) menyusun strategi bisnis restoran menu makanan khas Makassar; (3) menganalisis kepuasan konsumen yang sudah menjadi pelanggan restoran dengan menu makanan khas Makassar. Lokasi penelitian dilaksanakan di Restoran Khas Makassar Marannu dan Karebosi Kelapa Gading. Metode analisis data yang digunakan adalah Metode Matriks EFE (External Factor Evaluation) dan IFE (Internal Factor Evaluation), Analisis IE (Internal External), SWOT (Strengths, Weakness, Opportunities and Threats), Customer Satisfaction Index (CSI) dan Importance Performance Analysis (IPA). Posisi matriks IE menunjukkan posisi strategi pertumbuhan dan stabil, strategi pertumbuhan ini didesain untuk mencapai kondisi pertumbuhan penjualan, pertumbuhan keuntungan dan pertumbuhan aset. Usaha yang dapat dilakukan adalah penetrasi pasar dan pengembangan usaha. Dari analisis SWOT didapatkan strategi pengembangan restoran makanan khas Makassar, yaitu (1) meningkatkan produktivitas, (2) meningkatan pelayanan, (3) meningkatkan efisiensi waktu dan pengadaan bahan baku, (4) meningkatkan volume penjualan dengan efektifitas pemasaran, (5) mempertahankan dan menjaga mutu produk yang dihasilkan, (6) meningkatkan loyalitas pelanggan, (7) meningkatkan teknologi produksi dan mutu produk, dan (8) memperbaiki mutu Sumber daya manusia (SDM). Hasil skor CSI 0,92 menunjukkan bahwa tingkat indeks kepuasan pelanggan terletak pada 0,81-1,00, berarti pelanggan merasa sangat puas terhadap restoran makanan khas Makassar; dan hasil skor IPA 4,665, yaitu sangat penting bagi konsumen. Secara garis besar terlihat bahwa kinerja pelayanan restoran makanan khas Makassar yang diberikan telah sesuai dengan apa yang diharapkan konsumen.
\end{abstract}

Kata kunci: kinerja pelayanan, loyalitas pelanggan, mutu produk

\begin{abstract}
The restaurant business is a commercial enterprise, that must be based on a sense of desire to get certain advantages, so in practice always calculate trade-offs, so in the end it expects profits. Research purposes: (1) identifying the internal and external factors restaurant food typical of Makassar, which can affect the development of the restaurant business; (2) formulation of business strategy typical food restaurant Makassar; (3) able to analyze customer satisfaction which has been a customer with of typical
\end{abstract}

\footnotetext{
${ }^{*}$ ) Korespondensi:

Jl. Perintis Kemercekaan km 10 Tamalanrea, Makasar 90245; email: amrullahtahang@yahoo.com
} 
food restaurant Makassar. The location study was conducted in Restaurants Makassar Marannu and Karebosi Kelapa Gading. The method used Matrix EFE (External Factor Evaluation) and IFE (Internal Factor Evaluation), Analysis of IE (Internal External), SWOT (Strengths, Weakness, Opportunities and Threats), Customer Satisfaction Index (CSI) and Importance Performance Analysis (IPA). IE matrix position indicates the position and stable growth strategy, growth strategy is designed to achieve the conditions of sales growth, profit growth and asset growth. Efforts to do is market penetration and business development. SWOT obtained development strategy Restaurants Makassar, namely (1) increased productivity, (2) improvement of service, (3) increasing the efficiency of time and raw material procurement, (4) increasing the volume of sales with marketing effectiveness, (5) sustain and maintain the quality of products The resulting, (6) to increase customer loyalty, (7) improve production technology and product quality and (8) improving the quality of human resources. Results obtained value CSI CSI score of 0.92 . This indicates that the level of customer satisfaction index lies at 0.81 to 1.00 , which means that the customer was very satisfied with the restaurants Makassar. While the score of IPA is 4.665, which is very important for consumers. Broadly speaking, it appears that the service performance Restaurants Makassar given in accordance with what is expected of consumers.

Key words: quality of products, customer loyalty, service performance

\section{PENDAHULUAN}

Bisnis yang tidak mengenal masa dan tidak pernah mati adalah bisnis usaha makanan dan minuman. Bisnis ini selalu ada di setiap wilayah atau tempat, untuk berbagai usia dan kelas masyarakat selalu membutuhkan makanan dan minuman, baik skala besar maupun kecil. Berdasarkan keadaan dan kenyataan yang ada, maka bisnis restoran merupakan bisnis yang sangat menjanjikan dan akan memberikan keuntungan yang sangat menggiurkan. Sebagian besar orang sangat ingin memiliki usaha, baik sebagai usaha tetap maupun sebagai usaha sampingan yang bisa dikelola dengan mudah. Rumah makan disebut juga sebagai restoran di Indonesia. Restoran merupakan kata serapan, berasal dari bahasa Perancis yang diadaptasi oleh bahasa Inggris yaitu restaurant, berasal dari kata restaurer, yang berarti memulihkan (Utami, 2013).

Menurut Lupiyoadi (2001) penentuan tingkat kepuasan pelanggan memiliki lima faktor utama yang harus diperhatikan oleh perusahaan, yaitu faktor mutu produk, faktor mutu pelayanan, faktor emosional, faktor harga dan faktor biaya. Harapan konsumen dapat diartikan sebagai keyakinan konsumen sebelum mencoba atau membeli suatu produk yang dijadikan standar atau acuan dalam menilai kinerja produk tersebut. Untuk membuktikan baik tidaknya mutu suatu produk, dapat diukur dari tingkat kepuasan konsumen (Jasfar, 2005).

Sumarwan (2003) mendefinisikan perilaku konsumen sebagai perilaku yang diperlihatkan konsumen untuk mencari, membeli, mengguna- kan, mengevaluasi dan menghabiskan produk dan jasa yang diharapkan akan memuaskan kebutuhannya. Sedangkan keputusan melakukan pembelian merupakan hasil dari suatu hubungan yang saling memengaruhi antara faktor-faktor kebudayaan, sosial, pribadi dan psikologi dari pembeli (Kotler, 2005).

Tujuan penelitian ini: (1) mengidentifikasi faktor internal dan eksternal restoran menu makanan khas makassar, yang dapat memengaruhi perkembangan bisnis restoran; (2) menyusun strategi bisnis restoran menu makanan khas Makassar; dan (3) menganalisis kepuasan konsumen yang sudah menjadi pelanggan restoran dengan menu makanan khas Makassar.

\section{METODE PENELITIAN}

Lokasi penelitian ini dilaksanakan di Restoran Khas Makassar Marannu dan Karebosi Kelapa Gading, dari bulan Januari sampai dengan Juni 2015

\section{Pengolahan dan Analisis Data}

1. Metode Diskriptif

Pengumpulan data mengenai informasi prospek pasar, bahan baku dan keuangan yang berkaitan dengan pasokan bahan baku yang telah dikeluarkan oleh bisnis restoran.

2. Matriks EFE (External Factor Evaluation) dan IFE (Internal Factor Evaluation).

Matriks EFE membantu pengambilan keputusan untuk meringkas dan mengevaluasi informasi lingkungan eksternal, yaitu ekonomi, sosial, budaya, demografi, lingkungan, 
politik, pemerintah, teknologi, dan sebagainya. Matriks IFE digunakan untuk meringkas dan mengevaluasi kekuatan dan kelemahan utama yang dihadapi perusahaan (Hendriyani, 2010).

3. Matriks Internal-External (IE)

Matriks IE digunakan untuk melakukan pemetaan terhadap skor total matriks IFE dan EFE yang dihasilkan dari audit eksternal dan internal perusahaan. Matriks IE terdiri atas dua dimensi, yaitu total skor dari matriks IFE dan total skor matriks EFE. Total skor matriks IFE dipetakan pada sumbu $X$ dengan skor 1,01,99 yang menyatakan posisi internal adalah lemah, skor 2,0-2,99 posisinya rataan, serta skor 3,0-4,0 adalah posisi kuat.

4. Analisis SWOT (Strengths, Weakness, Opportunities and Threats)

Menurut Rangkuti (2013), hampir setiap perusahaan maupun pengamat bisnis dalam pendekatannya banyak menggunakan analisis SWOT. Analisis ini mengidentifikasi berbagai faktor secara sistematik untuk merumuskan strategi perusahaan. Analisis ini didasarkan pada logika untuk memaksimalkan kekuatan (strengths) dan peluang (opportunities), namun secara bersamaan dapat meminimalkan kelemahan (weaknesses) dan ancaman (threats).

5. Customer Satisfaction Index (CSI)

Hendriyani (2010), menyatakan bahwa Customer Satisfaction Index( CSI) adalah fungsi dari weighted average (WA) dibagi highest scale (HS) atau skala maksimum yang dipakai dalam penelitian ini (skala 5) dikalikan 100\%. Kriteria indeks kepuasan pelanggan (IKP) menggunakan kisaran 0,00-1,00 (tidak puas hingga puas), dilihat pada Tabel 1.

Tabel 1. Kriteria nilai indeks kepuasan pelanggan

\begin{tabular}{c|l}
\hline NILAI IKP & \multicolumn{1}{|c}{ KRITERIA } \\
\hline $0,00-0,34$ & Tidak puas \\
$0,35-0,50$ & Kurang puas \\
$0,51-0,65$ & Cukup puas \\
$0,66-0,80$ & Puas \\
$0,81-1,00$ & Sangat puas \\
\hline
\end{tabular}

6. Importance Performance Analysis (IPA)

Menurut Umar (2003), IPA merupakan metode yang dapat digunakan untuk menganalisis respon konsumen terhadap bisnis restoran khas makassar secara deskriptif kuantitatif. Data skala interval diberi skor secara kuantitatif untuk dipakai dalam perhitungannya (Tabel 2).
Tabel 2. Skor tingkat kepentingan

\begin{tabular}{l|c}
\hline \multicolumn{1}{c|}{ Kriteria Jawaban } & Skor (Nilai) \\
\hline Tidak penting & 1 \\
Kurang penting & 2 \\
Cukup penting & 3 \\
Penting & 4 \\
Sangat penting & 5 \\
\hline
\end{tabular}

\section{HASIL DAN PEMBAHASAN}

Nama Restoran Marannu dalam bahasa Bugis Makassar artinya selalu gembira, senang dan menyenangkan. Restoran ini didirikan pertama kali pada tahun 1984 oleh seorang putra asli Makassar yang lahir di kota Ujung Pandang kala itu yang bernama Daeng Rannu. Sedangkan Rumah Makan Sop Konro Karabosi berawal dari sebuah warung kaki lima yang berdiri pada tahun 1968 di Lapangan Karabosi Makasar, menu andalannya sop konro yang memberikan cita rasa khas makasar yang menurut pemiliknya $\mathrm{Hj}$. Hanaping. Restoran Khas Makassar Marannu dan Karebosi ini berada di Kelapa Gading Jakarta Utara.

\section{Matriks IFE dan EFE}

Berdasarkan analisis lingkungan eksternal dan internal, diperoleh hasil berupa nilai matriks yang menentukan posisi usaha bisnis restoran Makassar untuk dijadikan acuan dalam memformulasikan alternatif strategi yang diperoleh. Perumusan strategi pemasaran ini tidak terlepas dari aspek dimensi lingkungan eksternal dan internal.

Berdasarkan hasil penjumlahan skor total pada matriks IFE dan EFE didapatkan nilai masing-masing 2,659 dan 2,576. Skor total yang terdapat pada matriks EFE menggambarkan dan mengindikasikan posisi usaha bisnis restoran Makassar stabil dalam merespon situasi eksternal yang dihadapi. Skor total IFE mengindikasikan posisi usaha bisnis restoran Makassar berada pada tingkat rataan yang mampu merespon iklim internal.

Nilai skor total kombinasi antara matriks EFE dan IFE digunakan untuk mengetahui posisi usaha bisnis restoran Makassar (Gambar 1). Berdasarkan kombinasi nilai EFE dan IFE didapatkan matriks IE. Nilai matriks IE berada pada posisi sel tengah (pertumbuhan/stabil). 


\section{Matriks IE}

Penentuan posisi strategi perusahaan dalam matriks IE didasarkan pada hasil total nilai matriks IFE yang diberi bobot pada sumbu $x$ dan total nilai matriks EFE pada sumbu y (David, 2006). Posisi matriks IE menunjukkan posisi strategi pertumbuhan dan stabil. Strategi ini didesain untuk mencapai kondisi pertumbuhan penjualan, pertumbuhan keuntungan dan pertumbuhan aset. Usaha yang dapat dilakukan adalah penetrasi pasar dan pengembangan usaha. Hasil matriks IE dapat dilihat pada Gambar 1.

Kegiatan untuk peningkatan pemasaran dan pelayanan merupakan salah satu formulasi strategi andalan utama bagi usaha bisnis restoran Makassar, disamping pengembangan kegiatan usaha yang bertujuan untuk mempertahankan usaha, yaitu agar terus berlangsung dan terhindar dari kehilangan penjualan dan kehilangan keuntungan. Hasil identifikasi dari kekuatan, kelemahan, peluang dan ancaman perusahaan digunakan untuk merumuskan alternatif strategi dengan matriks SWOT.

\section{Matriks SWOT}

Perumusan strategi diterapkan melalui identifikasi dan analisis faktor-faktor eksternal yang terdiri dari peluang dan ancaman, serta faktor-faktor internal yang terdiri dari kekuatan dan kelemahan. Penyusunan mekanisme operasional merupakan batasan kegiatan yang perlu dilakukan oleh perusahaan dalam proses pengembangan usaha jasa pasokan suku cadang dan pemeliharaan pada usaha bisnis restoran Makassar. Formulasi kebijakan kualitatif pada Tabel 3 dapat dirumuskan berikut:

a. Strategi S-O (kombinasi S1-S3 dengan O1-O4)

Dari hasil analisis diperoleh beberapa formulasi strategi seperti meningkatkan produktivitas untuk meningkatkan laba dan peningkatan pelayanan. Kondisi perusahaan saat ini memiliki tingkat penjualan dan distribusi yang belum kuat, maka jaringan pemasaran luas diperlukan, disamping adanya perolehan laba dalam per tahunnya harus terus dioptimalkan. Untuk itu diperlukan upaya meningkatkan produktivitas jaringan distribusi dan peningkatan pelayanan, baik dengan bahan baku maupun hasil industri guna meningkatkan penjualan. Dengan adanya kondisi ini, diharapkan usaha bisnis restoran Makassar dapat mengisi peluang melalui saluran pemasaran yang dimilikinya. Disamping itu, perusahaan diharapkan mampu memanfaatkan kebijakan pemerintah saat ini. Perkembangan bisnis usaha makanan merupakan salah satu bisnis yang sangat diminati oleh masyarakat, karena makanan merupakan kebutuhan untuk kelangsungan hidup yang akan terus dicari. Hal ini terbukti bisnis kuliner telah menjadi lebih kompetitif karena lebih banyak orang mulai masuk ke bisnis yang menguntungkan ini (Maidayanti, 2013).

b. Strategi S-T (kombinasi S1-S3 dengan T1-T5)

Dari hasil analisis diperoleh beberapa formulasi strategi, yaitu meningkatkan dan menjaga mutu produk yang dihasilkan untuk meningkatkan loyalitas pelanggan dan meningkatkan kerjasama melalui kemitraan yang saling menguntungkan. Usaha saat ini kurang menunjukkan kondisi kuat. Dalam menghadapi ancaman yang ada, maka strategi untuk menghadapi persaingan dan pengembangan usaha adalah melakukan pemberdayaan secara optimal terhadap sumber daya yang ada, baik modal, tenaga kerja maupun pengelolaan usahanya. Selain itu, komitmen perusahaan dalam meningkatkan mutu bahan baku dan mutu produk yang dihasilkan.

c. Strategi W-O (kombinasi W1-W3 dengan O1-O4)

Dari hasil analisis ini diperoleh strategi menekan biaya produksi dengan meningkatkan efisiensi, terutama dalam pengadaan bahan baku dan efektifitas pemasaran untuk meningkatkan laba usaha. Secara umum, usaha bisnis restoran Makassar memiliki kelemahan yang sama dengan usaha lainnya, yaitu pemasaran masih belum optimal. Usaha bisnis restoran Makassar memiliki peluang sangat besar yang seharusnya mampu ditangkap oleh pengusaha, namun demikian strategi yang dapat dilakukan adalah memenuhi tuntutan peluang, baik mutu maupun kuantitasnya. Strategi mempertahankan mutu dilakukan dengan pengendalian bahan baku dan pengawasan mutu produksi secara konsisten.

d. Strategi W-T (kombinasi W1-W3 dengan T1-T5)

Dari hasil analisis ini diperoleh strategi meningkatkan teknologi produksi dan mutu dengan standar mutu yang diinginkan oleh pasar dan memperbaiki saluran distribusi. Kelemahan utama usaha ini selain ketersediaan biaya produksi tinggi, juga jaringan 


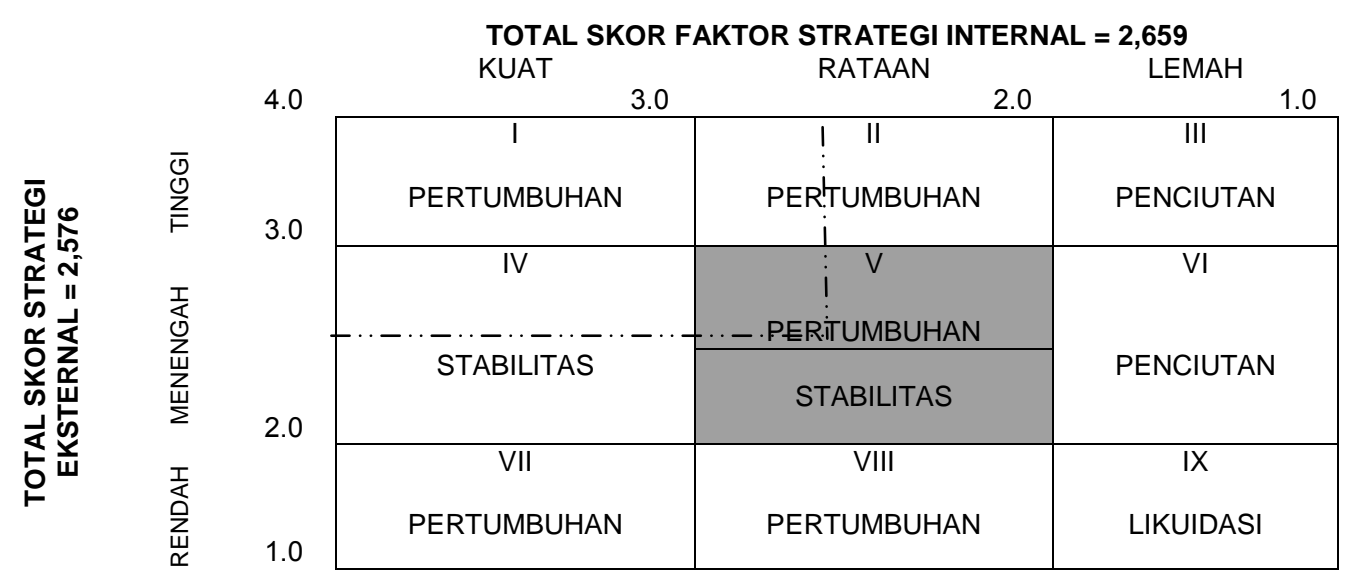

Gambar 1. Analisis Matriks IE

Tabel 3. Rumusan strategi pemasaran dengan matriks SWOT

\begin{tabular}{|c|c|c|}
\hline Faktor Eksternal & $\begin{array}{l}\text { Faktor kekuatan (S) } \\
\text { 1. Sistem Manajemen yang kuat } \\
\text { 2. Keuangan yang sehat } \\
\text { 3. Produksi yang optimal }\end{array}$ & $\begin{array}{l}\text { Faktor kelemahan }(\mathbf{W}) \\
\text { 1. Pemasaran } \\
\text { 2. Litbang usaha } \\
\text { 3. Sistem informasi belum optimal }\end{array}$ \\
\hline $\begin{array}{l}\text { Faktor peluang }(\mathrm{O}) \\
\text { 1. Daya tawar pemasok } \\
\text { 2. Daya tawar pembeli } \\
\text { 3. Fenomena sosial, budaya } \\
\text { dan demografi } \\
\text { 4. Fenomena teknologi }\end{array}$ & \begin{tabular}{ll|} 
Strategi SO (agresif) \\
1. & Meningkatkan produktivitas \\
& $(\mathrm{O} 1, \mathrm{O} 2, \mathrm{O} 3, \mathrm{O} 4 ; \mathrm{S} 1, \mathrm{~S} 2, \mathrm{~S} 3)$ \\
2. & Menerapkan standar mutu \\
& $(\mathrm{O} 1, \mathrm{O} 2, \mathrm{O} 3, \mathrm{O} 4 ; \mathrm{S} 1, \mathrm{~S} 2, \mathrm{~S} 3)$ \\
3. & Peningkatan pelayanan $(\mathrm{O} 3, \mathrm{O} 4 ;$ \\
& $\mathrm{S} 1, \mathrm{~S} 2)$
\end{tabular} & $\begin{array}{l}\text { Strategi WO (diversifikasi) } \\
\text { 1. Meningkatkan efisiensi waktu dan } \\
\text { pengadaan bahan baku } \\
(\mathrm{O} 1, \mathrm{O} 2, \mathrm{O} 3, \mathrm{O} 4 ; \mathrm{W} 2, \mathrm{~W} 3) \\
\text { 2. } \begin{array}{l}\text { Meningkatkan volume penjualan } \\
\text { dengan efektifitas pemasaran } \\
(\mathrm{O} 2, \mathrm{O} 3, \mathrm{O} 4 ; \mathrm{W} 1, \mathrm{~W} 3)\end{array}\end{array}$ \\
\hline $\begin{array}{l}\text { Faktor ancaman }(\mathrm{T}) \\
\text { 1. Persaingan dalam usaha } \\
\text { 2. Ancaman pendatang baru } \\
\text { 3. Ancaman produk substitusi } \\
\text { 4. Fenomena politik } \\
\text { 5. Fenomena ekonomi }\end{array}$ & \begin{tabular}{ll|} 
Strategi ST (diferensiasi) \\
1. & Mempertahankan dan menjaga \\
& mutu produk yang dihasilkan \\
& $(\mathrm{T} 1, \mathrm{~T} 2, \mathrm{~T} 3, \mathrm{~T} 4, \mathrm{~T} 5 ; \mathrm{S} 1, \mathrm{~S} 2, \mathrm{~S} 3)$ \\
2. & Meningkatkan loyalitas \\
& pelanggan $(\mathrm{T} 1, \mathrm{~T} 2, \mathrm{~T} 3 ; \mathrm{S} 1, \mathrm{~S} 3)$
\end{tabular} & $\begin{array}{l}\text { Strategi WT (defensif) } \\
\text { 1. Meningkatkan teknologi produksi } \\
\text { dan mutu produk (T1,T2,T3; } \\
\text { W1,W2,W3) } \\
\text { 2. Memperbaiki mutu SDM } \\
\text { (T1,T2,T3,T4,T5 ; W1,W2) }\end{array}$ \\
\hline
\end{tabular}

Keterangan : $(\mathrm{Oi} ; \mathrm{Si})$ atau $(\mathrm{Oi}$; $\mathrm{Wi})$ atau $(\mathrm{Ti} ; \mathrm{Si})$ atau $(\mathrm{Ti} ; \mathrm{Wi})$ menunjukkan kombinasi lingkungan eksternal dengan internal dalam menghasilkan pilihan strategi. $\mathrm{i}=1,2, \ldots \ldots . . \mathrm{n}$.

distribusi yang masih bersifat lokal. Oleh karena itu, strategi yang dapat dilakukan adalah memperbaiki mutu SDM dan gencar melakukan promosi melalui website, iklan diberbagai media massa dan elektronik.

Hubeis (2012) menjelaskan bahwa lokasi, atau distribusi merupakan kegiatan perusahaan membuat produksi tersedia bagi konsumen sasaran, dengan faktor penentu seperti akses, visibilitas, traffic, fasilitas kenyamanan, ekspansi, lingkungan, persaingan dan peraturan pemerintah.

\section{Analisis CSI}

Nilai rataan tingkat kepentingan dan tingkat kepuasan masing-masing atribut mutu jasa digunakan untuk menghitung CSI. Berdasarkan hasil perhitungan pada Tabel 4 didapatkan CSI 0,92. Hal ini menunjukkan bahwa tingkat indeks kepuasan pelanggan terletak pada 0,811,00 , maka dianggap pelanggan merasa sangat puas terhadap restoran menu makanan khas Makassar.

Kepuasan pelanggan akan timbul jika kebutuhan dan keinginan pelanggan dapat terpenuhi oleh produk bermutu. Puas atau tidaknya pelanggan terhadap suatu produk ditentukan 
oleh perilaku yang tampak setelah menggunakan produk tersebut. Pada umumnya bila pelanggan merasa puas terhadap suatu produk, maka akan dilakukan pembelian ulang terhadap produk tersebut. Bila hal ini terjadi dapat menimbulkan kesetiaan dari pelanggan terhadap produk tersebut. Pelanggan yang puas akan memberikan keuntungan bagi perusahaan, yaitu akan mengurangi persaingan terhadap barang dan merk yang sejenis (Winarta dan Kunto, 2013).

Tabel 4. Perhitungan CSI

\begin{tabular}{cccccc}
\hline Nomor Atribut & $\begin{array}{c}\text { Skor rataan } \\
\text { Tingkat } \\
\text { Kepentingan } \\
(\mathrm{a})\end{array}$ & $\begin{array}{c}\text { Importance } \\
\text { Weighting Factor }\end{array}$ & $\begin{array}{c}\text { Importance } \\
\text { Weighting Factor } \\
(\%)\end{array}$ & $\begin{array}{c}\text { Skor rataan } \\
\text { Tingkat } \\
\text { Kinerja } \\
(\mathrm{d})\end{array}$ & $\begin{array}{c}\text { Weighted Score } \\
(\mathrm{c})\end{array}$ \\
\hline 1. & 4,675 & 0,055 & 5,567 & 4,525 & 0,251 \\
2. & 4,600 & 0,054 & 5,477 & 4,475 & 0,245 \\
3. & 4,550 & 0,054 & 5,418 & 4,500 & 0,243 \\
4. & 4,725 & 0,056 & 5,626 & 4,600 & 0,258 \\
5. & 4,675 & 0,055 & 5,567 & 4,700 & 0,261 \\
6. & 4,775 & 0,056 & 5,686 & 4,700 & 0,267 \\
7. & 4,725 & 0,056 & 5,626 & 4,650 & 0,261 \\
8. & 4,550 & 0,054 & 5,418 & 4,550 & 0,246 \\
9. & 4,525 & 0,053 & 5,388 & 4,575 & 0,246 \\
10. & 4,400 & 0,052 & 5,239 & 4,450 & 0,233 \\
11. & 4,875 & 0,058 & 5,805 & 4,775 & 0,277 \\
12. & 4,750 & 0,056 & 5,656 & 4,675 & 0,264 \\
13. & 4,675 & 0,055 & 5,567 & 4,600 & 0,256 \\
14. & 4,725 & 0,056 & 5,626 & 4,575 & 0,257 \\
15. & 4,625 & 0,055 & 5,507 & 4,550 & 0,250 \\
16. & 4,725 & 0,056 & 5,626 & 4,625 & 0,260 \\
17. & 4,700 & 0,055 & 5,596 & 4,600 & 0,257 \\
18. & 4,700 & 0,055 & 5,596 & 4,725 & 0,264 \\
\hline Total Weighted & 83,975 & & 100 & & 4,604 \\
\hline TotalSatisfaction Index & & & & 0,920 \\
\hline
\end{tabular}

Tabel 5. Tingkat Penilaian Kinerja dan Kepentingan

\begin{tabular}{ccccccc}
\hline $\begin{array}{c}\text { Daftar } \\
\text { Pertanyaan }\end{array}$ & $\begin{array}{c}\text { Penilaian } \\
\text { Kinerja }\end{array}$ & $\begin{array}{c}\text { Penilaian } \\
\text { Kepentingan }\end{array}$ & $\mathrm{X}$ & $\mathrm{Y}$ & $\begin{array}{c}\text { Tingkat } \\
\text { Kesesuaian }\end{array}$ & Rangking \\
\hline 1. & 181 & 187 & 4,525 & 4,675 & 96,79 & 18 \\
2. & 179 & 184 & 4,475 & 4,600 & 97,28 & 16 \\
3. & 180 & 182 & 4,500 & 4,550 & 98,90 & 6 \\
4. & 184 & 189 & 4,600 & 4,725 & 97,35 & 15 \\
5. & 188 & 187 & 4,700 & 4,675 & 100,53 & 3 \\
6. & 188 & 191 & 4,700 & 4,775 & 98,42 & 7 \\
7. & 186 & 189 & 4,650 & 4,725 & 98,41 & 9 \\
8. & 182 & 182 & 4,550 & 4,550 & 100 & 5 \\
9. & 183 & 181 & 4,575 & 4,525 & 101,10 & 2 \\
10. & 178 & 176 & 4,450 & 4,400 & 101,13 & 1 \\
11. & 191 & 195 & 4,775 & 4,875 & 97,94 & 12 \\
12. & 187 & 190 & 4,675 & 4,750 & 98,42 & 8 \\
13. & 184 & 187 & 4,600 & 4,678 & 98,39 & 10 \\
14. & 183 & 189 & 4,575 & 4,725 & 96,82 & 17 \\
15. & 182 & 185 & 4,550 & 4,625 & 98,37 & 11 \\
16. & 185 & 189 & 4,625 & 4,725 & 97,88 & 13 \\
17. & 184 & 188 & 4,600 & 4,700 & 97,87 & 14 \\
18. & 189 & 188 & 4,725 & 4,700 & 100,53 & 4 \\
\hline Rataan & & & 4,602 & 4,665 & &
\end{tabular}


Restoran merupakan suatu usaha yang bergerak di bidang jasa, maka kepuasan konsumen sangat dipentingkan oleh para pengusaha restoran (Nikolay, 2014). Untuk itu, restoran menu makanan khas Makassar harus berkomitmen untuk meningkatkan kepuasan para pelanggan pada tahun-tahun berikutnya, agar mencapai kategori sangat puas (mendekati 100\%). Nilai CSI tersebut diharapkan dapat digunakan sebagai acuan oleh restoran menu makanan khas Makassar dalam menentukan kebijakan peningkatan kepuasan pelanggan di masa mendatang.

Keterangan:

$\mathrm{a}=$ Skor rataan tingkat kepentingan

$\mathrm{b}=$ Important Weighting Factor $\left(\mathrm{a} / \sum \mathrm{a}\right)$

$\mathrm{c}=$ Important Weighting Factor $\left(\mathrm{a} / \sum \mathrm{a}\right) \mathrm{x}$ $100 \%$

$\mathrm{d}=$ Skor rataan tingkat kinerja

$\mathrm{e}=$ Weighted Score

Dari Tabel 4 didapatkan atribut yang memiliki nilai rataan tingkat kepentingan dengan rating tiga (3) adalah atribut (11) halal, (6) kandungan gizi, serta (12) keramahan dan kesopanan pelayan. Untuk mengukur kepuasan pelanggan perlu diperhatikan selain mutu produk, seperti ciri khas apa yang dimiliki oleh suatu produk, sehingga berbeda dengan produk pesaing dan bagaimana jasa layanan yang diberikan oleh perusahaan. Hal pelengkap untuk mendapatkan kepuasan pelanggan adalah keramahan karyawan dalam melayani pelanggan dan penyampaian informasi secara tepat dan jelas, sehingga dapat memudahkan pelanggan untuk mendapatkan pengetahuan mengenai produk yang ditawarkan (Istianto dan Tyra, 2011).

Rincian analisis dari masing-masing atribut-atribut yang dikaji pada Tabel 4 adalah:

a. Halal

Makanan halal merupakan makanan sesuai tuntutan agama, bermutu dan tidak merusak kesehatan. Penduduk Indonesia mayoritas beragama Islam, maka halal menjadi syarat mutlak dalam makanan. Menu makanan khas Makassar menggunakan bahan baku makanan yang halal, sehingga pelanggan merasa yakin dan percaya bahwa makanan khas ini tidak akan merusak kesehatannya. Oleh karena itu, makanan halal menjadi rating tertinggi tingkat kepentingan. Tingkat kepentingan terhadap atribut ini dinilai sangat penting dengan nilai 4,875 dan penilaian kinerja dengan nilai 4,775, dengan skor tertimbang 0,277. Atribut ini menduduki peringkat pertama, sehingga layak untuk dipertahankan.

b. Kandungan gizi

Gizi adalah unsur yang terdapat dalam makanan dan dapat dimanfaatkan secara langsung oleh tubuh seperti halnya karbohidrat, protein, lemak, vitamin, mineral dan air. Menurut Purnomowati et al (2010), gizi adalah zat yang dibutuhkan oleh tubuh kita untuk pertumbuhan, mempertahankan dan memperbaiki jaringan tubuh mengatur proses dalam tubuh, dan menyediakan energi bagi fungsi tubuh, atau bisa juga diartikan sebagai komponen pembangun tubuh manusia. Oleh karena itu, kandungan gizi yang terkandung dalam makanan ini sangat diperhatikan pengelola dalam menyajikan menu makanan khas Makassar. Tingkat kepentingan terhadap atribut ini dinilai penting $(4,775)$ dan penilaian kinerja 4,700, dengan skor tertimbang 0,267. Atribut ini menduduki peringkat kedua, sehingga layak untuk dipertahankan.

c. Keramahan dan kesopanan pelayan, serta penyajian produk

Dalam industri makanan, sikap ramah dan senyuman saat pelanggan datang dan membeli, merupakan sikap yang mutlak dilakukan oleh karyawan, terlebih yang berorientasi kepada kepuasan konsumen. Tingkat kepentingan terhadap atribut ini dinilai penting dengan nilai 4,750 dan penilaian kinerja dengan nilai 4,675, dengan skor tertimbang 0,264. Atribut ini menduduki peringkat ketiga, sehingga layak untuk dipertahankan.

\section{Analisis IPA}

Dari Tabel 5 diperoleh gambaran perhitungan skor Likert, dengan nilai rataan tingkat kinerja pelayanan 4,602 atau diartikan mutu pelayanan pada restoran menu makanan khas Makassar adalah baik. Tingkat kepentingan pelayanan konsumen adalah 4,665, yaitu sangat penting bagi konsumen. Secara garis besar terlihat bahwa kinerja pelayanan pelayan restoran menu makanan khas Makassar yang diberikan telah sesuai dengan apa yang diharapkan konsumen.

Berdasarkan tingkat kesesuaiannya, terlihat atribut layanan memiliki nilai tingkat kesesuaian paling tinggi dan harus terus dipertahankan adalah (10) menu makanan khas Makassar, (9) kemudahan untuk memperoleh produk dan (5) kemasan produk. Atribut dengan tingkat kese- 
suaian paling rendah dan harus diperbaiki dan ditingkatkan, sehingga dapat memenuhi harapan konsumen adalah (18) citrarasa kelezatan, (14) kemudahan menghubungi perusahaan dan (2) bentuk dan ukuran.

Bisnis restoran meskipun memiliki prospek cukup bagus, tetapi juga sangat rentan, khususnya masalah konsistensi rasa, kontrol mutu dan pelayanan, sehingga pelaku di bidang ini membutuhkan pemahaman kuat tentang bisnis restoran, khususnya yang berkaitan dengan produk, mutu pelayanan, administrasi dan pengawasan (Sari, 2012).

Rincian analisis dari masing-masing atribut-atribut yang dikaji pada Tabel 5 adalah:

a. Menu makanan khas Makassar

Dalam daftar menu makanan khas Makassar terdapat menu yang lengkap dan komplit, serta bahan baku daging sapi impor lebih bermutu dibandingkan dengan bahan baku daging sapi lokal. Atribut ini dianggap sangat penting dalam memberikan kepuasan pelanggan. Hasil perhitungan terhadap tingkat kepentingan pelanggan pada atribut ini adalah 4,450 dan tingkat kinerja 4,400, serta tingkat kesesuaian 101,13. Pelanggan merasa atribut ini dinilai sangat baik, sehingga perlu dipertahankan dan tetap ditingkatkan. Keamanan makanan merupakan kebutuhan masyarakat, karena diharapkan melalui makanan yang aman, masyarakat akan terlindungi dari penyakit atau gangguan kesehatan lainnya (Nurlaela, 2011).

b. Kemudahan memperoleh produk

Dalam memperoleh produk, pelanggan dapat memperoleh informasi secara lengkap dan jelas dari brosur, leaflet maupun iklan. Informasi yang lengkap dan jelas secara langsung, baik melalui brosur dan leaflet masih menjadi pilihan utama pelanggan. Hasil perhitungan terhadap tingkat kepentingan pelanggan pada atribut ini 4,575 dan tingkat kinerja 4,525, serta tingkat kesesuaian 101,10. Dalam hal ini, pelanggan merasa bahwa atribut ini dinilai sangat baik, sehingga perlu dipertahankan dan terus ditingkatkan.

c. Kemasan produk

Kemasan merupakan salah satu solusi untuk menarik perhatian konsumen karena berhadapan langsung dengan konsumen. Seiring dengan berkembangnya jaman dan meningkatnya persaingan, fungsi kemasan yang dulunya hanya sebagai wadah atau pelindung berubah menjadi alat jual yang memberikan dan menciptakan citra kepada produk yang dijualnya (Cenadi, 2000). Produk yang dikemas atau tampilan produk dalam menu makanan khas Makassar sangat menarik minat pelanggan untuk terus datang di Restoran Makassar. Kemasan dan tampilan higienis ini sangat disukai pelanggan. Hal ini menandakan manajemen restoran khas Makassar memperhatikan kebersihan dan kesempurnaan makanan khasnya. Hasil perhitungan terhadap tingkat kepentingan pelanggan pada atribut 4,700 dan tingkat kinerja 4,675, serta tingkat kesesuaian 100,53, sehingga pelanggan merasa bahwa atribut ini dinilai sangat baik, maka perlu dipertahankan dan terus ditingkatkan. Merubah kemasan yang lebih menarik dengan visual dan struktur (material dan bentuk) yang lebih estetis secara tidak langsung ikut menambah jumlah semakin besar yang berindikasi terhadap laba bersih perusahaan (Hidayat, 2009).

\section{KESIMPULAN}

Hasil skor total pada matriks IFE dan EFE IFE dan EFE adalah 2,659 dan 2,576. Dari kombinasi nilai EFE dan IFE didapatkan matriks IE pada posisi sel tengah (Pertumbuhan/Stabil). Hal ini menggambarkan dan mengindikasikan posisi usaha bisnis Restoran menu makanan khas Makassar stabil dalam merespon situasi eksternal yang dihadapi.

Berdasarkan SWOT didapatkan strategi pengembangan Restoran atas menu makanan khas Makassar, yaitu: (1) meningkatkan produktivitas, (2) menerapkan standar mutu, (3) peningkatan pelayanan, (4) meningkatkan efisiensi waktu dan pengadaan bahan baku, (5) meningkatkan volume penjualan dengan efektifitas pemasaran, (6) mempertahankan dan menjaga mutu produk yang dihasilkan, (7) meningkatkan loyalitas pelanggan, (8) meningkatkan teknologi produksi dan mutu produk, serta (9) memperbaiki mutu SDM.

Hasil skor CSI 0,92, menunjukkan tingkat indeks kepuasan pelanggan terletak pada 0,81 1,00, maka diartikan pelanggan merasa sangat puas terhadap Restoran menu makanan khas Makassar. Hasil skor IPA adalah 4,665, diartikan sangat penting bagi konsumen. Kedua hal tersebut menunjukkan bahwa kinerja pelayanan pelayan Restoran menu makanan khas Makassar 
yang diberikan telah sesuai dengan apa yang diharapkan konsumen.

\section{DAFTAR PUSTAKA}

Cenadi, C.S. 2000. Peranan Desain Kemasan Dalam Dunia Pemasaran. Jurnal Nirmana, 2 (1): 92-103.

David, F.R. 2006. Manajemen Strategi (Terjemahan). PT Prenhallindo, Jakarta.

Hidayat, M.J. 2009. Analisis Industri Budaya pada Desain Produk Kemasan Makanan Industri Kecil Menengah (IKM). Jurnal Pendidikan Seni Budaya, 1 (2): 141-151.

Hendriyani, E. 2010. Analisis Kepuasan Konsumen Terhadap Produk Roti "Breadhouse " Untuk Menentukan Strategi Pengembangan Usaha. Bogor (ID). Sekolah Pascasarjana Institut Pertanian Bogor.

Hubeis, M. 2012. Manajemen Ritel Kreatif dan Inovatif Dalam Bisnis. Inti Prima Promosindo, Jakarta.

Istianto, J.H dan M.J. Tyra. 2011. Analisis Pengaruh Kualitas Layanan Terhadap Kepuasan Pelanggan Rumah Makan Ketty Resto. Jurnal Ekonomi dan Informasi Akuntansi (Jenius), 1 (3): 275-293.

Jasfar, F. 2005. Manajemen Jasa-Pendekatan Terpadu. Ghalia Indonesia, Bogor.

Kotler, P. 2005. Manajemen Pemasaran. Alih Bahasa Benyamin Mohan. Edisi 11, Jilid 1. PT. Intan Sejati Klaten, Jakarta.

Lupiyoadi, R. 2001. Manajemen Pemasaran Jasa Teori dan Praktek. Salemba Empat, Jakarta

Maidayanti, G.H. 2013. SWOT Analysis Usaha Rumah Makan Pondok Ale-Ale Pontianak. Jurnal Pendidikan dan Pembelajaran, 2 (12): $1-9$.
Nikolay, F.R. 2014. Studi Kelayakan Pendirian Restoran Seafood dengan Mempertimbangkan Kansei Engineering dalam Perancangan Interior Ruangan di Maumere, Kabupaten Sikka, Nusa Tenggara Timur. Calyptra Jurnal Ilmiah Mahasiswa Universitas Surabaya, 3 (2): 1-19.

Nurlaela, U. 2011. Keamanan Pangan dan Perilaku Penjamah Makanan di Instalasi Gizi Rumah Sakit.Jurnal Media Gizi Masyarakat Indonesia, 1 (1): 1-7.

Purnomowati.I, Diana H dan C. Saparinto. 2008. Aneka Kudapan Berbahan Ikan. Kanisius, Yogyakarta.

Rangkuti, F. 2013. Marketing Strategy E Competitive Positioning. PT Gramedia Pustaka Utama, Jakarta.

Sari, A.I. 2012.Tingkat Kepuasan Konsumen pada Mutu Pelayanan Rumah Makan (Studi pada RM Jawa Deli, RM Putri Minang dan RM Tak Bernama di Kampung Susuk, Kampus USU Medan). Jurnal Keuangan dan Bisnis, 4 (2): $148-159$.

Sumarwan, U. 2003. Prilaku Konsumen. Teori dan Penerapannya dalam Pemasaran. Ghalia Indonesia, Jakarta.

Umar, H. 2003. Riset Pemasaran dan Perilaku Konsumen. PT Gramedia Pustaka Utama, Jakarta.

Utami NDPA, Citrakesumasari dan St. Fatimah. 2013. Kandungan Zat Gizi Makro dan Pengaruh Bumbu terhadap Angka Peroksida per Porsi Coto Makassar. http://repository.unhas.ac.id/handle/123456 789/3292. Diakses tanggal 12 Maret 2014.

Winarta, R.C dan Y.S. Kunto. 2013. Pengaruh Kualitas Rumah Makan Bromo Asri Terhadap Kepuasan. Jurnal Manajemen Pemasaran, 1 (1): 1-10. 